\title{
Apiin-induction of $\beta$-apiosidase production by Aspergillus sp. strains
}

\author{
Klaudia Karkeszováa, Viera Illeováa, Peter Kis ${ }^{\mathbf{b}}$, \\ Vladimír Mastihuba ${ }^{b}$, Milan Polakoviča \\ ${ }^{a}$ Department of Chemical and Biochemical Engineering, Institute of Chemical and Environmental Engineering, \\ Faculty of Chemical and Food Technology, Slovak University of Technology, \\ Radlinského 9, 81237 Bratislava, Bratislava, Slovakia \\ ${ }^{b}$ Institute of Chemistry, Slovak Academy of Sciences, Dúbravská cesta 9, 84538 Bratislava, Slovakia \\ milan.polakovic@stuba.sk
}

\begin{abstract}
Apiosidase is a rare glycosidase applied in winemaking for flavour enhancement. This enzyme is involved in the release of volatile terpenes by hydrolysis of their odourless glycosidic precursors. It is found as a minor component in commercial pectinase/cellulase preparations. Microbial production of $\beta$-apiosidase by two Aspergillus sp. strains was investigated. Apiin-induced production of this extracellular glycosidase was confirmed only during the cultivation of Aspergillus niger CBS 554.65 but the high productivity value reported in the work of Dupin et al. (1992) J. Agric. Food Chem. 40(10): 1886-1891 could not be reproduced. The achieved productivity was by far not satisfactory considering the apiin cost. Commercial enzyme preparations with $\beta$-apiosidase side-activity thus remain a better alternative as the enzyme source for biocatalytic applications.
\end{abstract}

Keywords: $\beta$-apiosidase, Aspergillus niger, Aspergillus aculeatus, cultivation

\section{Introduction}

The role of aroma compounds in wine has been in the centre of interest for many decades. It is well established that the glycoconjugates of monoterpenes are one of the most influential sources of wine aroma (Mateo and Jiménez, 2000; Maicas and Mateo, 2005; Ruiz et al., 2019). There has been a continuous research on the enhancement of wine quality and aroma by an addition of exogenous enzymes to improve the liberation of a volatile aglycone linked by a glycosidic bound to glucose or disaccharides comprising $\beta$-D-glucose at the reducing end (Günata et al., 1988; Williams et al., 1989; Günata et al., 1990; Cabaroglu et al., 2003; Palomo et al., 2005) .

In case of disaccharides, the second monosaccharide attached to glucose can be arabinose, rhamnose or apiose. Hydrolysis of disaccharide-containing glycosides takes place in two steps. The mentioned monosaccharides are first released by the action of specific glycosidases. In the second step, $\beta$-glucosidase hydrolyses the resultant glucosidic linkage and releases the free aromatic compound (Günata et al., 1988; Günata et al., 1990).

$\beta$-Apiosidase is a glycosidase involved in the cleavage of apiosylglycosides. Properties, production and purification of this enzyme were intensively studied for the first time in 1990's (Dupin et al., 1992). Depending on grape variety, the level of apiosylglycosides can reach up to $50 \%$ of the total glycoside content (Mateo and Jiménez, 2000). On the other hand, $\beta$-apiosidase is present in very low amounts in the enzymatic systems of grapes and yeast or it is even absent. Hydrolysis of grape glycosides can be therefore enhanced through enrichment of the enzymatic activity by exogenous glycosidases (Günata et al., 1990; Cabaroglu et al., 2003; Sarry and Günata, 2004; Castro Vázquez et al., 2002; Spagna et al., 2002).

Abundant levels of $\beta$-apiosidase side activities were identified in some fungi-derived enzyme preparations formulated for their pectinase or cellulase activities. Fungi-originated glycosidases were observed to be more stable in wine $\mathrm{pH}$ compared to those of plant origin (Cabaroglu et al., 2003; Sarry and Günata, 2004). Dupin et al. (1992) showed that the production of $\beta$-apiosidase by Aspergillus niger can be induced by an addition of apiin to the culture medium. Likewise, the presence of Tween 80 $(0.15 \% \mathrm{v} / \mathrm{v})$ and peptone $(2.0 \% \mathrm{w} / \mathrm{v})$ also enhanced the synthesis of this glycosidase. The enzyme was partially purified from the culture extract and some of its characteristics were determined. Günata et al. (1997) purified $\beta$-apiosidase from an Aspergillus niger enzyme preparation and characterised this glycosidase in detail. Guo et al. (1999) achieved tenfold $\beta$-apiosidase purification degree from the same preparation. Characteristics of the isolated and purified $\beta$-apiosidases are shown in Table 1. 
Table 1. Properties of isolated $\beta$-apiosidases.

\begin{tabular}{|c|c|c|c|c|c|}
\hline $\begin{array}{l}\text { Product } \\
\text { (Enzyme source) }\end{array}$ & $\begin{array}{c}\text { Specific activity } \\
{[\mathrm{nkat} / \mathrm{mg}]}\end{array}$ & $\begin{array}{l}\text { Purification } \\
\text { factor }\end{array}$ & Optimum pH & $\begin{array}{c}\text { Optimum } \\
\text { temperature }\left[{ }^{\circ} \mathrm{C}\right]\end{array}$ & Ref. \\
\hline $\begin{array}{l}\text { Cultivation supernatant } \\
\text { (A. niger CBS 554.65) }\end{array}$ & 6150 & 9.4 & 5.6 & 50 & $\begin{array}{l}\text { Dupin et al. } \\
\text { (1992) }\end{array}$ \\
\hline $\begin{array}{l}\text { Klerzyme } 200 \\
(\text { A. niger })\end{array}$ & 216 & 27 & 6 & $50-60$ & $\begin{array}{c}\text { Günata et al. } \\
\text { (1997) }\end{array}$ \\
\hline $\begin{array}{l}\text { Klerzyme } 200 \\
\text { (A. niger) }\end{array}$ & 1285 & 270 & 5 & 40 & $\begin{array}{l}\text { Guo et al. } \\
\text { (1999) }\end{array}$ \\
\hline
\end{tabular}

A renewed interest in $\beta$-apiosidase has recently been observed with the aim of investigating its potential in biocatalytic synthesis of specialty chemicals. Kis et al. (2016) examined the occurrence of $\beta$-apiofuranosidases in 45 samples of commercial enzyme preparations and in eight samples of plant materials. The enzyme was identified in 16 enzymatic preparations, from which the highest $\beta$-apiosidase activity was found in Rapidase AR 2000, Lallzyme BETA, Amano $\alpha$-galactosidase DS, Viscozyme L and Novozym 188. All preparations exhibiting $\beta$-apiosidase activity originated from Aspergillus sp. (Kis et al., 2016). Reaction mechanism of exo-acting $\beta$-apiosidase found in Viscozyme $\mathrm{L}$, a product of Aspergillus aculeatus, has recently been studied in detail by Mastihuba et al. (2019). Results obtained from experiments using H NMR spectroscopy revealed the inverting mechanism of the enzyme, which is therefore unable to provide transglycosylation reactions. Exo- $\beta$-apiosidase can anyway find applications not only in terpenyl glycosides hydrolysis but also in lignocellulosic biomass degradation. However, endo-apiosidase cleaving $\beta$-apiofuranoside bonds in rhamnogalacturonan-II found in gut bacterium Bacteroides thetaiotaomicron can reportedly provide the retaining mechanism (Ndeh et al., 2017).

Since there is no commercially available $\beta$-apiosidase and its activity in commercial pectinase/cellulase preparations is relatively low, the objective of this work was to investigate the potential of two Aspergillus strains, Aspergillus niger CBS 554.65 and Aspergillus aculeatus CBS 101.43, to produce $\beta$-apiosidase using plant-isolated apiin as the inducer.

\section{Materials and methods}

\section{Materials}

Aspergillus niger CBS 554.65 and Aspergillus aculeatus CBS 101.43 were purchased from Westerdijk Fungal Biodiversity Institute (Utrecht, The Netherlands). Enzyme preparation Viscozyme L (protein concentration of $85 \mathrm{~g} / \mathrm{l}$ as given by the producer), a product of Novozymes (Bagsværd, Denmark), was purchased from Biotech (Trnava, Slovakia). A synthetic substrate, 4-nitrophenyl $\beta$-D- apiofuranoside, for the detection of $\beta$-apiosidase activity was synthesised using the chemoenzymatic procedure described by Kis et al. (2016). Crude apiin (65\% according to HPLC) was prepared by extraction from parsley leaves using a proprietary in-house procedure based on the method of Hulyalkar et al. (1965). Oxoid bacteriological peptone was purchased from Thermo Fisher Scientific Inc. (Waltham, Massachusetts, USA). Tween 80 was obtained from Sigma Aldrich (Steinheim, Germany). Other culture medium and buffer components were of analytical grade and were purchased from Centralchem (Bratislava, Slovakia).

\section{Cultivation conditions}

Purchased lyophilized fungal cultures Aspergillus niger CBS 554.65 and Aspergillus aculeatus CBS 101.43 were grown on agar plates containing potato dextrose agar at ambient temperature $\left(25^{\circ} \mathrm{C}\right)$. Based on the supplier's recommendations, spore inoculum was collected after three weeks of revitalisation. Suspension of spores was prepared by washing the agar plates by $5 \mathrm{ml}$ of sterilised $0.1 \%$ Tween 80 solution. Total concentration of the harvested spores was determined microscopically by counting them in a Bürker chamber. Composition of the cultivation medium for $\beta$-apiosidase production was adopted from Dupin et al. (1992). Experiments were conducted in $50 \mathrm{ml}$ Erlenmayer flasks containing $20 \mathrm{ml}$ of liquid medium consisting of the following nutrients (\% w/v): $\mathrm{MgCl}_{2} \cdot 6 \mathrm{H}_{2} \mathrm{O}, 0.1$; $\mathrm{KH}_{2} \mathrm{PO}_{4}, 0.1$; apiin, 1.0; peptone, 2.04; and Tween $80,0.15(\% \mathrm{v} / \mathrm{v})$. After sterilisation in an autoclave, the flasks were inoculated with $1 \times 10^{6}$ spores of fungi and incubated at $30^{\circ} \mathrm{C}$ in a rotary shaker at $140 \mathrm{rpm}$ for seven days. The culture broth was centrifuged at $5000 \mathrm{rpm}$ and $5^{\circ} \mathrm{C}$ for 15 minutes. Supernatant with the secreted enzyme was filtered through a $0.22 \mu \mathrm{m}$ polyethersulfone syringe filter. The clear filtrate was used as a source of extracellular enzyme for the assays.

\section{Enzyme activity assay}

$\beta$-Apiosidase activity in the culture filtrate and Viscozyme L preparation was determined using a 


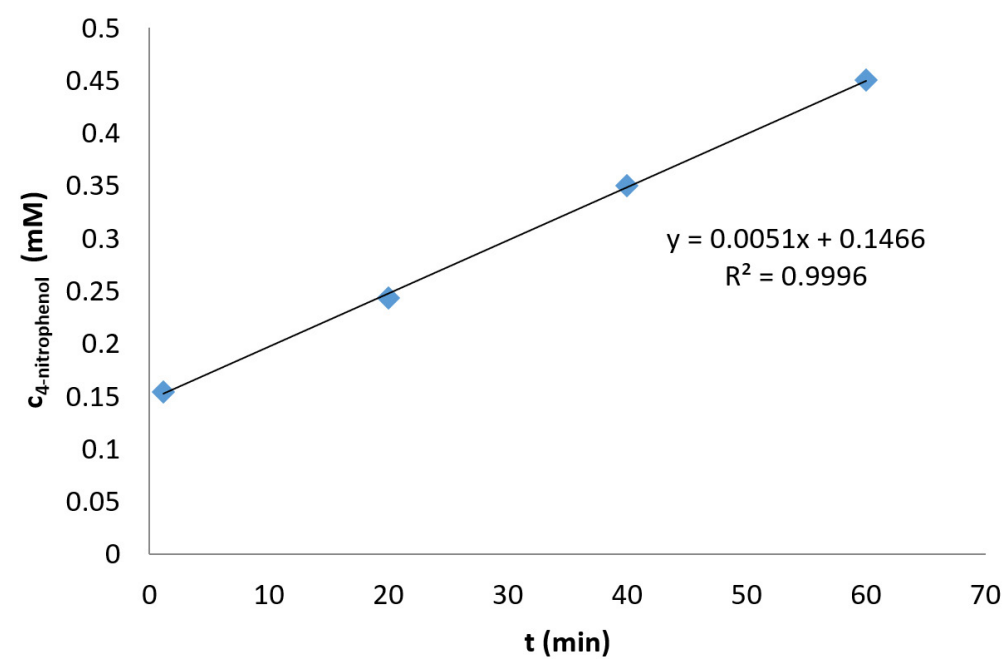

Fig. 1. Apiosidase activity measurement using the initial rate method.

slightly adapted method described by Dupin et al. (1992). The assay was conducted by incubating a properly diluted sample and $2.2 \mathrm{mM}$ 4-nitrophenyl $\beta$-apiofuranoside in a $0.1 \mathrm{M}$ acetate buffer $(\mathrm{pH} 4.4)$ at $40{ }^{\circ} \mathrm{C}$. The reaction was initiated by adding the enzyme solution to the synthetic 4-nitrophenyl substrate in the volumetric ratio of 1:1. $\beta$-Apiosidase activity was determined using the initial reaction rate method (Fig. 1). Samples at different time intervals were withdrawn from the assayed mixture in 20-minute intervals and added to $0.1 \mathrm{M} \mathrm{Na}_{2} \mathrm{CO}_{3}$ to stop the reaction. Concentrations of the released 4-nitrophenol were evaluated from the absorbance measured at $405 \mathrm{~nm}$. The activity was expressed in nanokatals per volume of the enzyme sample.

\section{Protein assay}

Total protein concentration was estimated according to the bicinchoninic acid (BCA) assay. Suitably diluted aliquots of culture filtrate were used for the determination in microplates. Formation of a purple-coloured complex was measured at $562 \mathrm{~nm}$ after 30 minutes of incubation at $37{ }^{\circ} \mathrm{C}$. Bovine serum albumin was used as a protein standard.

\section{Results and discussion}

The main motivation for this work was the disparity between the $\beta$-apiosidase activity in nowadays enzyme preparations reported in the paper of Kis et al. (2016) and that reported in selected 1990's papers (Table 1). As it follows from Table 1, crude preparation of Klerzyme 200 had the activity of 5-8 nkat/mg. Table 2 shows that Viscozyme L, selected as the best enzyme source by Kis et al. (2016) considering its price and availability has the specific activity by one order of magnitude lower. It is difficult to interpret this difference by the former preparation being obtained by A. niger cultivation whereas the latter one is a product of A. aculeatus. Kis et al. (2016) examined 13 commercial enzyme preparations of Aspergillus species and all but one $A$. niger preparation showed no $\beta$-apiosidase activity. However, the last one, Novozym 188, had the second highest activity after Viscozyme L. Variation of the $\beta$-apiosidase side-activity by two orders of magnitude in this kind of preparations is thus common.

Since these commercial preparations are rather crude protein concentrates, it can be expected that $\beta$-apiosidase specific activity was not significantly reduced during downstream processing. Specific activity in the corresponding cultivation broth could be very similar. From this point of view, the results of A. niger laboratory cultivation presented by Dupin et al. (1992) are striking. As shown in Table 1, they achieved a specific activity of more than $6,000 \mathrm{nkat} / \mathrm{mg}$ at a small purification degree. The corresponding $\beta$-apiosidase specific activity in the cultivation broth was about $650 \mathrm{nkat} / \mathrm{mg}$. An interesting aspect of the work of Dupin et al. (1992) is that, without induction by apiin, no detectable $\beta$-apiosidase activity was observed for any of the four investigated A. niger strains. Moreover, they found that the enzyme yield increased 50 -fold when the basal medium was supplemented with peptone as nitrogen source and surfactant improving the enzyme release from cells.

These results inspired the investigation of the option of preparing sufficient amount of $\beta$-apiosidase for the respective biocatalytic research. Two strains, Aspergillus niger CBS 554.65 and Aspergillus aculeatus CBS 101.43, were selected for this purpose. The former one was used by Dupin et al. (1992) and the latter one was probably used to produce Viscozyme $\mathrm{L}$ since this strain is typically found in patents filed 
by Novozymes (Dörreich et al., 1993). Optimal conditions for induced $\beta$-apiosidase production were adopted from the work Dupin et al. (1992). A medium with the concentration of crude apiin of $1.0 \% \mathrm{w} / \mathrm{v}$ was used.

Unfortunately, the cells of A. aculeatus CBS 101.43 were unable to grow in the chosen medium. Evidently, apiin is not a convenient carbon source for this strain. Consequently, the work focused on the cultivation of A. niger CBS 554.65. The cultivation was carried out for seven days. The cell biomass was subsequently removed from the culture broth by centrifugation and $\beta$-apiosidase activity in the supernatant was determined by the initial reaction rate. Table 2 shows that the final value of $\beta$-apiosidase activity was $0.79 \mathrm{nkat} / \mathrm{ml}$, which is remarkably lower than the values of 200-300 nkat/ml declared by Dupin et al. (1992). It should however be emphasised that more typical values of $\beta$-apiosidase activity of about 3-4 nkat/ml were achieved due to the induction by apiin. The enormous increase of the mentioned values was achieved only by the change of the nitrogen source and surfactant permeabilisation of cell membrane. It is also interesting that substitution of the laboratory grade apiin with a very crude apiin source, parsley seeds, resulted in the activity decrease to several nanokatals per millilitre.

Thus, lower purity (about $65 \%$ ) of used apiin is a potential reason of lower levels of apiosidase activity in our experiments. On the other hand, apiin purification costs are very high. Several chemical suppliers currently offer 95-99 \% apiin from $5 € / \mathrm{mg}$ to $220 € / \mathrm{mg}$ depending on the package size. The lowest unit price is for $100 \mathrm{mg}$ package. Considering the optimal apiin concentration of $1 \%$, even the best price results in the apiin cost of $30,000 € / 1$ of cultivation medium. Obviously, this cost is simply unaffordable. A cultivation experiment was made using $1.0 \%$ glucose as the carbon source instead of apiin but it did not provide a positive result. As it was also observed by Dupin et al. (1992), A. niger CBS 554.65 cells cannot produce $\beta$-apiosidase when they grow on glucose.

Tab. 2. $\beta$-Apiosidase activity in examined enzyme preparations.

\begin{tabular}{lcc}
\hline Enzyme preparation & $\begin{array}{c}\text { Activity } \\
\text { (nkat/ml) }\end{array}$ & $\begin{array}{c}\text { Specific activity } \\
\text { (nkat/mg) }\end{array}$ \\
\hline $\begin{array}{l}\text { A. niger } \text { CBS } 554.65 \\
\text { cultivation broth }\end{array}$ & 0.79 & $>0.2^{*}$ \\
Viscozyme L & 29 & 0.3 \\
\hline
\end{tabular}

*Due to the interference of residual peptone, the measured protein concentration can be overestimated.
As it follows from Table 2, cultivation using crude apiin resulted in $\beta$-apiosidase specific activity comparable to that of Viscozyme L but in a much less concentrated form. The idea of overproduction of this desired enzyme via apiin induction thus appears less advantageous. Viscozyme L produced by Aspergillus aculeatus represents an available and economical source of $\beta$-apiosidase. It can be a suitable source for further purification to obtain a biocatalyst free of undesired enzymatic activities.

\section{Conclusions}

Induced production of $\beta$-apiosidase by two strains of filamentous fungi of the genus Aspergillus was examined. Aspergillus aculeatus CBS 101.43 was not able to grow in the cultivation medium optimised by Dupin et al. (1992) for the overproduction of $\beta$-apiosidase by a strain of Aspergillus niger. This fact is fully understandable since the composition of nutrients in the medium can be very specific for each strain. The second investigated strain, Aspergillus niger CBS 554.65, exhibited induction of $\beta$-apiosidase production by apiin but the level of apiosidase activity was not sufficiently high probably due to the use of crude apiin. On the other hand, very high cost of pure apiin makes this approach to the $\beta$-apiosidase production not feasible. Thus, the use of commercial enzyme preparations with $\beta$-apiosidase side activity identified in two dozens of enzyme preparations by Kis et al. (2016) is a better alternative.

\section{Acknowledgement}

This work was supported by grants from the Agency of the Ministry of Education, Science, Research and Sport of the Slovak Republic for Structural Funds of EU (Grant number: ITMS 26240220071) and the Slovak Research and Development Agency (Grant numbers: APVV-16-0111 and APVV-18-0188).

\section{References}

Cabaroglu T, Selli S, Canbas A, Lepoutre JP, Günata Z (2003) Enzyme Microb. Technol.

Dörreich K, Christensen FM, Schnell Y, Mischler M, Dalbøge H, Heldt-Hansen HP (1993) WO 93/20193.

Dupin I, Günata Z, Sapis JC, Bayonove C, M'Bairaroua O, Tapiero C (1992) J. Agric. Food Chem. 40(10): 1886-1891.

Güunata Z, Bitteur S, Brillouet JM, Bayonove C, Cordonnier R (1988) Carbohydr. Res. 84: 139-149.

Günata Z, Bayonove CL, Tapiero C, Cordonnier RE (1990) J. Agric. Food Chem. 38(5): 1232-1236.

Günata Z, Dugelay I, Vallier MJ, Sapis JC, Bayonove C (1997) Enzyme Microb. Technol. 21(1): 39-44.

Guo W, Salmon JM, Baumes R, Tapiero C, Günata Z (1999) J. Agric. Food Chem 47(7): 2589-2593. 
Hulyalkar RK, Jones JKN, Perry MB (1965) Can. J. Chem. 43: 2085-2091.

Kis P, Potocká E, Mastihuba V, Mastihubová M (2016) Carbohydr. Res. 430: 48-53.

Maicas S, Mateo JJ (2005) Appl. Microbiol. Biotechnol. 67: 322-335.

Mastihuba V, Karnišová Potocká E, Uhliariková I, Kis P, Kozmon S, Mastihubová M (2019) Food Chem. 274: $543-546$

Mateo JJ, Jiménez MJ (2000) J. Chromatogr. 881(1-2): $557-567$.

Ndeh D, Rogowski A, Cartmell A, Luis AS, Baslé A, Gray J, Venditto I, Briggs J, Zhang X, Labourel A, Terrapon N, Buffetto F, Nepogodiev S, Xiao Y, Field RA, Zhu
Y, O’Neil MA, Urbanowicz BR, York WS, Davies GJ, Abbott DW, Ralet MC, Martens EC, Henrissat B, Gilbert HJ (2017) Nature. 544(7648): 65-70.

Palomo ES, Hidalgo MDM, Gonzalez-Vinas MA, PérezCoello MS (2005) Food Chem. 92(4): 627-635.

Ruiz J, Kiene F, Belda I, Fracassetti D, Marquina D, Navascués E, Calderón F, Benito A, Rauhut D, Santos A, Benito S (2019) Appl. Microbiol. Biotechnol. 103: $7425-7450$.

Sarry J, Günata Z (2004) Food Chem. 87(4): 509-521. Spagna G, Barbagallo RN, Greco E, Manenti I, Pifferi PG (2002) Enzyme Microb. Technol. 30(1): 80-89.

Williams PJ, Sefton MA, Wilson B (1989) ACS Sym. Ser. 35-48. 